\title{
Role, Opportunities and Challenges of Collaboration and Interface Indian and Iranian Cinema
}

\author{
Kaveri Devi Mishra \\ The Papua New Guinea University of Technology, PAPUA NEW GUINEA \\ (iD) 0000-0002-4417-0525 \\ averi5050@gmail.com
}

Maryam Vaziri

Mysore University, INDIA

(D) 0000-0002-3169-2818

\begin{abstract}
ARTICLE INFO
Received: 23 May 2019

Accepted: 9 June 2019

Published: 23 July 2019

DOI: https://doi.org/10.29333/ojcmt/5857

ABSTRACT

This is an explanatory study based on library and secondary data about the cultural and artistic communication between countries of Iran and India in past and current status. India is an important trans-regional hub in cinema that has own culture and style which also influence other countries even on people life style or movies of different directors. In the other hand, Iran is a country with younger cinema industry which still has amount of good films and profession directors who are in touch with India and influence each other. They caused more interaction between these two great countries. Although the Iranian style of movies has different aspects from Indian, but beside of cultural and sociological impact, we cannot also deny the collaboration between directors and artists. The main question of this study is how we can use this cultural aspect in the future for the better communication between these two communities.
\end{abstract}

Keywords: film, cinema, India, Iran, collaboration, interaction, influence, culture

\section{INTRODUCTION}

Elements of cinema website explained Cinema or film is an art of painting; it is an intuitive environment that tells stories and displays reality. The cinema was built in the 19 th it is also very complex, cooperation and cost in art. Hollywood was made a colourful economic film. Special effects created. Digital was invented a century ago and the film industry is still flourishing. Today, cinema can be portrayed as an artwork of moving animated images that grows with sounds and music. Travis Hansen, 2011, the national cinema produces films that have the cultural and historical significance of the country. Countries with national cinema are able to produce films that examine their nation through their narrative forms, cultural values, beliefs, and views of their identity. These works can be the successor to the individual and experiences of life in that country. Also, they can reveal parts of the art that depict the aspects of a nation or people within a nation that otherwise might be unknown to an alien. In any case, any film produced by a large Hollywood company or an independent group of funds will provide an insight into the cultural values and beliefs of filmmakers and the places they are or will become more familiar with. In intercultural communication, foreign films can turn the insights of other 
people from other countries into the history, heritage, and cultural elements of the country, which makes the country unique. But there is a precaution to be taken into account, because all films cannot be considered a "truth" about a country. Hollywood producers tend to have many films about other countries and their history, in this regard audiences must know that what they watch is not the truth, but the reality that filmmakers perceive. Sometimes movies can be fooled by viewers to be sure of what they see. This could lead to misunderstandings and cultural misunderstandings that lead to stereotypes and possible generalizations. Travis Hansen, 2011, the movie is a super powerful medium. Languages, concepts, categories, ideas of thought, and representation systems - that different classes and social groups to create sense, define, formulate and present a comprehensible way of society. National cinema is very important for the nations; citizens in one country can often be identified with films that are made by people who live in similar situations like them. Also, foreigners can stop the first hand of culture, as it sees and knows and begins to understand how life lives in a particular culture. One of the great things about the movie is that it's timeless (Hansen, 2011).

Hoster Parnon pointed out in which Kindon is entitled Potential of Deformation of Participatory Video, not only shows that Video Participatory is an effective tool that cannot reach and express the views of traditional groups in community development processes, but these consequences for the structure of relationships between researchers and the researchers are the participants. Kindon has argued that the need for those who work in the visual arena, there is the participation of visual technology away from participation in unrealistic forms of visual notes through the use of films, and participation in more empowerment. Conventional social science research relies on foreign experts to be able to view and extract data from passive topics in a short time, while it may be a way for men to win. Tsiyuan (2008) explained cinema is a theatre, minus the techniques and conventions used at the theatre stage. Cinema is photography minus the congenital.

White (2003) over the past two decades, media and cultural globalization reached another level of development and influence. While the markets (national), various media outlets for powerful and comprehensive media outlets such as News Corp., Disney and Time Warner, Media Development in East Asia and Asian Cultural Production, Media Production, Production and Circulation and consumption without conversion has become less evident. On the one hand, changes in the patterns of cultural production, circulation and communications from the west are shown. However, on the other hand, it is still suspect that if these changes ultimately translate into transnational cultural media, the flow of media of honest and $t$ relations between people from different points in order to promote communication is, as a hierarchy, roughness and marginalization. Given the fact that countries support the activities of transnational media and cultural industries, researchers need to study more precisely, injustice and marginalization in the cultures of the Asian network and transnational cooperation with various social actors in order to link Asia-culture Dialogue is in a democratic way. The culture of the media of East Asia is not only well received in the country. Their national borders, especially in other parts of East Asia, have also disappeared. It points to another trend that the globalization of media is regional communication so that the remote command has increased the production and distribution of media culture in Europe and the United States. Additionally, the promotion of Asia and the simultaneous production of joint cultural media have become transnational with the growing cooperation between the media and 
the cultural industries in the region of close cooperation with the aim of pursuing international markets for joint marketing and investment.

Grassilli (2008) this is especially true of guitarist production and guitarist style in Italy, while analysing the impact of cultural policies on production and representation. To give with the definition of immigrant cinema or "cinematic accent," as a condition for Hamid Nafisi's position in a broad theoretical framework, it reflects the aspects of diversity, identity and cultural participation, focusing on production and distribution as much as they have a multinational strategy from international cooperation, communication and cooperation beyond the colonial flow after colonialism and the new dynamics created by digital technology. All of these opportunities and alternatives derived from the transnational nature of the status of filmmakers in the film industry, combined with the features of digital technology allow immigrant filmmakers to express creativity beyond the limits of public policy, minority protection and diversity. Expand cultural filmmaking. The transnational nature of the film industry, the global possibilities for interacting with the Web and digital technology, all the border constraints and problems that the filmmaker may be in conditions / conditions for the movement of the experience. However, lack of recognition at the national, local, and lack of cultural diversity in cultural politics in many countries continues to maintain the identity and self-esteem characteristics necessary to encourage creativity to express their impact.

\section{RESEARCH METHODOLOGY}

\section{Research Problem}

India is an important trans-regional hub in cinema that has own culture and style which also influence other countries even on people life style or movies of different directors. In the other hand, Iran is a country with younger cinema industry which still has amount of good films and profession directors who are in touch with India and influence each other. They caused more interaction between these two great countries. Although the Iranian style of movies has different aspects from Indian, but beside of cultural and sociological impact, we cannot also deny the collaboration between directors and artists.

\section{Research Question}

The main question of this study is how Cinema as an important cultural and creative form of communication forge mutual cultural collaboration and in the future for the better communication between Iranian and Indian people.

\section{METHOD}

This is an explanatory study based on library and secondary data that researches about the cultural and artistic communication between counties of Iran and India in past and current status.

Indian Aspect

Manu Sharma, (2014), the culture of structural reform is the natural flow of affairs. It has been stated by Krishnamurti and Bohm culture can take the form of some a kind of targeting, guiding features or properties of objects - From plants, domesticated animals or kids - in the process Development. This is a valuable term that can be used to determine a group of people who "share with each other" is a valuable joint feature. According To Wallace, each culture brings with it three kinds of relationships People. Firstly, people belong to the culture, which means that a system relative of all persons belonging to culture, in the second phase, culture belongs to individuals, which means this cultural 
tool has been brought to the personal world of mind they direct mentality in a unique and cultural way. Thirdly, the culture belongs to related individuals and the environment, which means that culture becomes different the processes people associate with their world. Anthra stated culture is a dynamic system of thoughts that allows us to distinguish between accepting or rejecting conditions or actions. We rely on our culture for images and vocabulary will help us respond to our social and personal environment. Most importantly, mass media help create this culture, in addition to reflecting it. So culture becomes a symbolic system in which all media are Manufacturers and media users work. Media acts within a culture and uses its symbols. This includes defaults and stereotypes. Manu Sharma, 2014, Christopher Raj and Andrew McMurray explained as far as the analysis of culture in the multicultural society is concerned, this concept is to build a collective identity as one Well from others. Although accepting host culture Society is the easiest way to accept, immigrants are unchangeable consider host culture as the greatest threat to their identity. The normative dimension and the value of culture are part of the socialization process at the individual and collective levels. As an art, as a communication medium, codes and symbols, by intellectuals working on cinema and cinema studies have given many ideas which emphasize somewhere that cinema is related to different types of art as an art form the complexities of society, which can be analysed through multiple ways. Manu Sharma, 2014, so we also have a glimpse of transnational cinema not only leads to the discovery of diversity but its extensive effects. Indian transnational cinema, India cultural diversity in the most innovative way with efficient use Colours, cultural signs and structures across borders. But nevertheless the creative connection remains in the limited social image Ethnic and existing philosophies, issues; problems space is not much time. Although an observation is interesting that transnational film India discovers the themes that mix concepts with Popular Concepts "are not very talked about. The Indian Film and Television Institute (FTII) diluted for the moral hazard and therefore it is composed the goals and objectives. Other environmental changes are fundamental to building this institution, but it has the right to freedom of expression and individual thinking. This institution has become a bigger goal than privatization and globalization and today's decision-making by the authorities to generate profits, not an industry education centre. If these changes do not stop immediately and reverse the tide, this country will forever lose people the only field of training for those who are committed to meaningful and community-oriented cinema. The program was presented in 1961 with the aim of promoting the replacement of alternative cinema and the creation of new standards at both speeds. The film industry is very professional, focused and specializing in various aspects of film making. The National Films of the Country of India (NFAI), the National Film Development Film Company (NFDCF), has been one of the pillars of cinema that has promoted the diversity of media voices. It is unique in all film schools in the world, providing an opportunity to test exploratory examples. The government has been planning all the sectors of the community to provide premium filmmakers with experience in accessing global equipment and exposure to the best cinema in the world. This great series of movies in the National Film Archives has served as a rich source for learning. Together, two powerful bases for talent are growing. Koichi Iwabuchi (2010) is basically a lot of people in East Asia, like three film productions like the Seven Swordsman. East Asian markets are increasingly coordinated, and manufacturers, executives, as the capital of the region in a variety of creative activities that go beyond national boundaries. It is especially important at the present time that by pushing the market between nationalism, governments have also strongly promoted the cultural 
policies that led to the production and export of national media culture. In East Asia, the best-known example of government policies for selling Korean culture, which is the development of the Korean wave (Shim, 2006). Similarly, many national governments in East Asia, such as Japan, China, Singapore, Taiwan, Thailand and India, are also interested in pursuing this policy. They recognize the symbols as cultural ambassadors and national dishes abroad. The problem of national trade policy is its ideological closure on the fundamental issues of globalizations it promotes public debate about the culture of media to national interests on the international scene at the expense of engaging with a wide range of people. Governments actively support global market-based globalization, not to promote public debate on the vital issues of the media of the culture of globalization. Anirudh Deshpande (2007) explained reviewing of Indian cinema against the bourgeoisie, assuming the advancement of modernity and the implementation of modernization in India. Historically, this is an elite class that interacts with the traditional Indian colonial rule. The national project of this heterogeneous class, the colonial history, after colonialism and neo-colonial India, is always problematic. Indian cinema shows the country in different fields. The conclusion of cinema in colonial India was influenced by censorship as a state ideology, the elite's preferences. The Indian cinema company is exaggerated by the early restrictions of colonialism, the relatively safe myth and the unintended or targeted consequences. This genre, with rare exceptions, is their cultural perception of producers and directors. The bourgeois intellectuals decided to upset their deeply religious community in their films. The concept of the culture of religion has left the culture to leave the options. Encoding the legends of the screen, history and people from the upper floor, began to monitor the middle class. Vasudevan said that Indian cinema in the "fuzzy" colonial society has been considered despite restrictions. Perhaps nationalist rhetoric is strong enough to hide the congregation. Still, enduring images that take Indian cinema to the masses are always dangerous for both collective and political uncertainty. As a result, Indian cinema became a popular love, family and nation. Three people in this national project combine bourgeois temptation in the former colony. In fact, the end of the British colonial rule brought the Indian bourgeoisie to power and seriously began the process of constructing the Indian nation. Mass media were in the development of the history of tourism. The movie genres boasted more detail in order to produce general stereotypes and for some time to come. After the colonialization, the purpose of the cinema to sort the community into the interests of the elite of power in independent India - the cinema after 1947 was the opium of the masses. As a microcosm of the community, family class values, nursery classes, anchored ideological hometown cinema offer an alternative value to the film dedicated to social struggles. National and international norms of caste buildings and patriarchy of Hollywood cinema have been commended. The family is a legendary propaganda showcasing the great temptations of India with family values. Chakraparti and Paraser showed that the ideological class of the working class, the patriarchal and predominantly Indian bourgeois family of cinema is post-colonial India. Religious minorities and other marginalized groups appear to act as a stereotype or remove it. This issue arises in many issues that monotheistic domination and Hindi Indian society may be disappointing. In total, India's shareholding in Indian cinema is divided among communities, while long-standing relationships with India's nationalism have been established over the past two decades. The requirements of this relationship, though, have not changed during the three-phase history of bourgeois development mentioned in this article. Bollywood anti-hegemonic reform and other languages have steadily grown over the past 20 years. Marie SETON (1975) In all countries that broadcast 
better international movies, displaying videos and organizing them commercially, custom ads may be designed to attract. Smart audience exists. Television channels have devoted a significant amount of time each week to promote cinematic knowledge. In this way, artistic films are called as part of general cultural life. Nowadays in Europe, an Iranian movie, an Egyptian movie, a Bengali film, a movie has been accepted as much as it has been accepted in Swedish, French, Spanish or German. Movie quality is important. Susmita Dasgupta (2005), by the so-called commercial show of cinema so that the top high fashion in India has begun its very humorous managers for the mood. One including Farah Khan, who trivialises the first time in such a healthy situation that even a good viewer Ramgopal Varma in his film, as a tribute to the parents of audience audiences creating enough disorder without it, audiences may accurately read the spirit of the film. In Sarkar, incidentally, Amitabh played the role of a godfather, as he plays police officer in many of his films or the role of a trafficker in a number of products are equally exciting. He also remained in the band Amitabh Bachchan and did not play any father. In this perspective, it can be seen that the film may be better commercial cinema. Appeal to the Indian Film World, these people revolved around the class, society and views. Unfortunately, on the days of globalization, the ethics of society in terms of the integration of people from all spheres of life, the middle class collapses in favour of selfishness. Indian cinema is now seeking popularity with this global middle class worldwide. Indian cinema as a result of changes in popular form and ideology is a direct result of the theatre changing its base from a diverse population to the male-Indian movement around the world. It is obvious that the age that he holds Amitabh and is a MEGASTAR past, but in RemgaPhal's film, it seems that ideology is still important. If inequality is rising in the world, if hunger deaths are shattered by many developing countries, if poverty can still solve the primary property, such as education, health and housing, how does the ideology of any kind become a part? Globalization believes that private capital is capable of meeting the needs of society, which is because the welfare state and socialism did not do this. But a decade of globalization in India has shown that private capital has done so badly and not worse than the government. At the same time, at a logical level, all deprived people claim that common sources point out that Amitab Bachanana as a star is a major paradox of government; some people have access to basic relationships such as education, housing, health and Denied social justice. The contradictions of the Bachchan film are inherent in the periods around this law unchangeable. Now, it seems that these points are deeper: neoliberal commands are not ideological opposition to this policy. It works in a very small way to defeat a neoliberal agreement.

\section{Iranian Aspects}

Houshang Kavousi, a well-known critic selected a name "Film-Farsi" of prerevolutionary cinema for a series of films with a structure and common features such as hasty storytelling, dancing heroes, dancing and singing songs without communication with the story, the lack of causal relationships, unrealistic passions, incidents, etc. These films were generally made with Hollywood and Indian cinema. In the narrative s of these films, there was usually the use of fictitious storytelling and superstitious narrations and superficial humour, and their element of suspense and anxiety was more closely related to unwanted comedy. The characters of these films were usually familiar to the familiar socialist types and were more likely to be identified as individuals with individual identities. Actors in such films, even if they were poor, were wearing expensive clothes and were usually beaten in love stories for their beloved ones. During the years after the revolution, the Cinematics returned to the Iranian cinema in various forms, and in some 
cases, which has not been low, has been welcomed by the audience. ZaidabadiNejad (2007) Iranian cinema is international importance in relation to Iran's filmmaking and discourse identity policies. Iran began a new wave of the 1960s and 1970s and praised Iran's interpretation of the films at the time and their relationship with the discourse on the West or the West's tensile show. The internationally acclaimed cinematic interaction facilitated the importance of social and political issues in the country. Examples of Iranian intellectuals' offices in the world outside of Iranian cinema inevitably fall into the discourse of identity. Since the 1990s, the internationally conscious self-conscious reaction has been evident. Iranian films do not want to see the primitive west of modernity. This reaction, which compared to the pre-revolutionary period, can partly affect the social change and acceptance of reformists after the revolution Islamic is the modern identity of Iran. It is a modern aspect. As the film shows, the importance of the festival provides many opportunities for a willingness to participate in politics. Some Iranian filmmakers who did not want to participate in social affairs, their films were heard in public speeches. For example, Abbas Kiarostami is great to make use of making political films about children, including where a friend is a friend to spell out social criticism. While the opening of political space since 1997 has contributed to this change, multinational funds as well as international dramatic filmmakers have been effective. As filmmakers in the world have become famous, they can take on Iranian audiences about social criticism / political issues, critical interaction with filmmakers of social reality in Iran's position in the "national". ZaidabadiNejad (2007) Zaid Fanon shows that it does not do this and instead, to get to know people with the worldview, intellectual tension, and "spiritual poverty" although he cannot believe that filmmakers are expected to restrict creativity to the national space, it is surely true that in making the film only the values of the elite are attracted to the wisdom, filmmakers are driven to the exclusion of serious policies at the national level. At the same time, many of the films that are strongly associated with the urban social reality appeal to film makers while at the International Film Festival, the world famous phenomena have contributed to the improvement of the characteristics of cinema in Iran. During the Pahlavi regime, the western program runs with a fist and tries to boost its image through media, including the film supporting the regime and exhibitions that show the progress of the country. The film industry, which generally refers to the ideology of the regime, refers to the production of a culture of commercial cinema, which often includes songs and dances, which called filmfarsi as a movie as an imitation of the cinema of India and Egypt. Shahab Esfandiari (2011) Despite the fact that one of the pioneers of the "New Wave" of Iran's Cinema in the 1960s, the position of Mehrjuei retained the influence of cinema as a filmmaker. He is still able to make films that are both popular with the general public and praise critics of Iran. Mehman e Maman (Mom`s Guest), a social comedy made in 2004, is one of the films criticized slightly outside of Iran. Ejareh Neshinha (tenants, 1986), is another popular social comedy that made by Mehrjui almost two decades ago. This comparison is compared to determine the difference between the two films according to postmodernist and globalization theories. The argument is that Mehrjui represents the nation in the mom's guests, showing that they are more aware of class differences, gender, ethnicity, and religion. And a more comprehensive approach to the marginal sectors of society. The fall of the boundaries between "local" and "global" as well as "high art" and "low art" are other key elements of the recent movie of Mehrjui. The film also looks at how it encompasses issues such as happiness and solidarity, political / ideological contradictions, and science and consumption, which is described, with reference to the effects and consequences of globalization. Using such images, which 
reveal the dark part of local and national culture, is a key step for tenants, a moment of reconciliation, cooperation and entertainment, and a potential for solidarity. Mehrjuei's social comedy, endorsed by Iranian critics as one of the best examples of national cinema, was compared to themes, styles and admissions. Both films can be classified as social comedy and have been very popular among public audiences. The main purpose of the comparison, however, was to identify the difference between the two films, based on the former, in the mid-1980s and the second half of 2000. It was said that while confessing to a middle class tenant who was inefficient - driven by a political greed more profound than a rivalry and conflict - he could not come to an agreement and save his homes from destruction. At the bottom of the community, guests recognize Mom and not only manage the characters to overcome their differences and misery, but also succeed in collaborating on a single project. Unlike tenants, Mom's guests are the largest display of the innocent community and politics. This film can be used as a postmodernist degree, and globalization can see the disappointment with "great narratives." In representing extreme poverty, unemployment, domestic violence, drug addiction and internal displacement caused by the war, the mom's guest does not romanticizes "local" or "national", nor is it indifferent to the plight of the residents. The film is also "political" in the sense that it shows suppression and invasive aspects of local culture, values and inspiration, rather than corruption, intercultural knowledge and enjoyment of foreign cinema. Moment guests are also able to recognize the difference, hoping to recognize the possibility of solidarity between the various nations.

\section{COLLABORATION AND INTERACTION BETWEEN IRAN AND INDIA}

Ramachandran (2016) at the Film Festival for the 60th Anniversary of the Cultural Convention between New Delhi and Tehran which is jointly hosted by the Ministry of Information and Broadcasting, the Council for Indian Cultural Relations (ICCR) and the Iranian Embassy in New Delhi, also featured art forms in Iran. It was decided that an old association with Iran display through cultural exchanges, including the Arts, Literature, Film and Music Festival. Dr. Abuzar Ebrahimi, head of the Islamic Culture and Communication Organization [ICRO] to participate in the program. IANS (2016) Mohammad Reza Golzar, Iranian move star says he is learning Hindi for the first time in Iran to play a role on the film "Salaam Mumbai". This is the first project between Iran and India and he thinks it would be a good start, because can make a bridge between Iran and India. Two to three Iranian actresses / actresses, Bollywood stars, and five Indian actresses in flip-flops are produced by filmmaking companies. IRNA, 2016 it is the first joint Bollywood production between Iran after the 1979 Islamic Revolution. Iran was also the first transistor when the first Persian speech film called Lor Girl in India with the help of Ardeshir Irani, the name that was produced at the beginning of India's first album of music in Almara. Abdul Hussein Spentha made the first soundtrack. Ardeshir in India is a writer, director, producer, actor, film distributor, film producer and cinematographer in India's cinematic cinema. It shows past memories of the past with the magnificence and joint venture of two real people, this is a dream, revolutionary endeavour in contemporary cinema and its future. According to advanced technology in British India, producer and director Abdul Hussein Spent realized that he could display Iran's first feature film. In 1931, he started with Ardeshir, a Persian from the local community, producing Lor Girl. This was the first film with the people to speak for the first time as a female actor in a Muslim country as a producer. The final film, Leili and Majnoun, was in the form of a complete dramatic poem similar to Romeo and Juliet. The Basravi family 
has made many of the accessories that the script has built-in such as detailed information on internal and external scenes, dialogue, and cast movements, settings, dresses, lights, sound effects and camera movements added. Although four other scripts are available, none of them do that accurately. According to the Business of cinema website, 2007, Majid Majidi, known for making films that show human emotions and dilemmas such as "God's colour", "rain" and the nominal concentration of Oscar, "Children of Paradise", to work with UTV in India. According to the news of the project, it is said to be "Kashmir float. He has been looking for a movie in India and has received a lot of suggestions. Manish Gaekwad, 2017, Majidi says is ready to travel to Jaipur for the next program. He does not like to shoot inside studios and prefer outdoor spaces and found India a lovely place with a lot of talent for flourishing, but unfortunately, Bollywood films do not address a lot. He believes India gave him the good feeling that was anticipated for the story that if the film is made in India, strongly that the connection will be repeated. He has been watching closely with Bollywood films and is familiar with space. He visited a number of places that have taken films in the past and spent time at the studios. His complaint about Bollywood filmmakers is that they do not try to be realistic about the world that surrounds them. They do not use the full potential of the country. Majidi has a huge reputation in Iran as well as throughout the world. Bobby Sing (2016) "Remembering Subah-O-Sham, the first Indian film in Iran" Although the first Indian-Iranian project in filming a movie is one of those films and Indian cinema of the country, including Its famous star. The IndianIranian film was released as a project by Mohammad Ali Fardin in 1972, as one of its actors (as noted), and with more support from Simin Ghaffari. They cast Sangif Kumar and Indian actors under the command of Chanakya Vahide Rahman (known as Ram Aur Shyam). Mina Carnik (2016) Many young directors, especially Maharashtra, are still under the influence of Iranian cinema, and this is clearly reflected in the work. This is what reaches the Iranian pavilion in the mines. Kamiyar Mohsen is a critic and teacher, researcher and executive director with FCF in the last twelve years. The Fajr International Film Festival, started in 1982 select films in Iran and also support Iran's cinema. Farabi Foundation is the only importer of foreign films which claimed sometimes plays the movie which is not Hollywood movies, but it's good in Asian and European countries, and it also reads educational films for students to better understand the film. Some of them have been making films that are admired by foreign buyers. Apart from Iran's official booth, there is another small Iranian station located on different floors. "One of the booths that you visit the government is the mine of an independent distribution company, and we do not get money from the government, they choose their own people," says International Marketing Director Marjan Alizadeh. "They produce films made by independent filmmakers while we are young, the creators of the first distribution. Of course we cannot make any kind of film, we see different stories, it's not necessary to be political." Shahin Parmami (1999) at the end of the second session of the school, Ohanian's next project was another comedy named Hajji Aqa Aktore-cinema 1933. This film was not well in the box office. Not only are there technical shortcomings, but also the release of the first Persian transistor produced in India has reduced its prospects for profit. After the defeat of the second film, Ohanians did not find any other support for other activities. He left Iran for India and continued his career in Kolkata. Times of India (2013) reported the film festival will strengthen the relationship between India and Iran and is looking for more films. Zara Knox (2016) 50s and 60s in Iran saw the flood of cheap films that destroyed the style of the Indian and American cinema, which belong to a genre known as Farsi Hollywood movie, song, dance, and glamor, Following is a strange feeling: The 
Silent Movie, 1962 in Delhoreh (anxiety), as Former Iranian and Armenian Director Samuel Khadhikian from Iran's Hitchcock. The display of wealth, the gathering of corruption and women in low costumes were compulsory. And modernity of the West with films such as Siamak Yasami (Ganj Qaroun) in 1965 and Amir Naderi (Goodbye Friend) in 1970. Now, in the present time, Sanjay Mito believes that there is a great deal of similarity between Indian culture and many Iranians. In an exclusive interview with IRNA at the New Delhi Film Festival, Sanjay Mito expressed he connects with Iranian artists and people. The film can show these connections in Iran, and India will succeed and help the people of both countries learn more about each other." He added to continue this process the Indian government should organize a film and Indian cultural festival in Iran in order to preserve the exchange of culture and art between the two streams. Danian Hosseini, 2016, Sometimes it's just a way of spending the huge budgets that they have at their disposal, and they do not know what to do with it, sometimes for use, to make stunning movies that excuse international stories or the universal moral look of the camera abroad. A commercial like the recent movie named "I am not Salvador", was featured at the beginning of the year. In this case, leaving the country offers more opportunities to make the filmmaker attractive, including bypassing the veil, which is the most notable and usually the most notable one. But if used appropriately, the visual features of the second country and the presence of characters and the culture and the atmosphere in the film can be beneficial and create a more serious attraction.

\section{Salam Mumbai!}

Mohsen Zohrabi (2016), Salam Mumbai is a love movie that incorporates some of the components of this genre into its structure. The love pattern of the poor boy to the rich girl has a long history in the Indian and Iranian cinema. There is not a trick in the narrative of the story, nor in the creation of nodes opened up by the intelligence of characters or their attempts. The film has practically no dramatic storyline and is based on its ability to engage the audience on the appearance of characters and the atmosphere of film and sexual attraction and the theme of its red line. The narrative of the film is that the most important parts of the story in the letter or the monologues are the characters. For example, the letter Krishma writes to Ali, at the end of the story, opens the most important node of the story, and this is the most startling and fastest way to narrate in the script. Meytham Karimi believes "Salam Bombay" begins with an introduction in which a young doctor treats a subject with his old friend and returns to India, and then the entire length of the film is narrated in a flashback from the perspective of the main character of the story; a narrative that disturbed and troublesome. The big problem with the film, which is more than any other weakness, is the screenplay. It seems that the script by Chorban Mohammadpour is directly related to the 70's and 80's of Indian cinema, because most of the filmmaking formulas used in this work is like the narrative logic of those years of cinema. The "Salam Bombay" script, without the slightest logic of narrative in it, is full of romantic moments that the filmmaker used, instead of trying to create situations that inspired the love of characters, using India's fascinating images and situations. The romance, which often resembles the methods of wedding clips, is filled up so that the viewer is fascinated by the image and does not consider much content. The film also features two completely over-the-top characters with Benyamin Bahadori and his wife, Shilli Mahmudi, who is unclear if the role of the movie sales has been limited to choosing to play the film. Daniyal Hosseini, 2016, explained features that are responsible for most of the noise of the film and is also featured in the movie's name, is in India. In this context, Mumbai's greetings because the presence in India is a prerequisite for the 
film's storyline, and most of the characters in the film have been chosen by people of their own language and culture. It cannot be cut off that the film could not be made in another country. But the current romance and dance and the songs are related to the places that are pleased at this level of cinema. Several songs have been heard in happy and sad emotional moments of the film, a series of Hindi and a number performed by Benyamin Bahadhi, the accompaniment of songs with the emotional moments of the film of the same formulas that operate on a commercial level and increase the quality of entertainment. The film did not take much of India's visual features, apart from a few side by side beaches that could have been anywhere else, and exhibits from the faculty of medicine, the remaining sequences, or the interior, or filmed in places that do not have unique visual characteristics. But the transportation system of India is well featured in the movie, and the joke with taxi engines called Rickshaw is in the film. Masoud Ferasati (2016) expressed "Salam Bombay" is vulgar, offensive and anti-Semitic. He stated we need to think about the fact that we are in a situation where our people are forced to watch such an unfinished film, pre-cinema, directing, acting and screenplay. He emphasized he is opposed to the joy of people and the simple funny movie, but "Salam Bombay" owes to both the Persian film and the Indian movie! This film exploits the worst form of need for love, emotion and affection. Many people talk about love, how they are talking about love is our problem, he believed. Milad Khodabandeh (2016) explained the movie "Salam Mumbai" has nothing to do with showing a postal card image of India's and the experience of making a common product between the two countries. Ali Mansouri (2016) shared Mohammad Reza Golzar is undoubtedly the only actor in Iran's cinema, which has been moving toward being a star, and to a large extent, has succeeded in achieving it. Certainly Starr is someone whose audience is willing to pay for seeing him. And the writer does not know the other actress that the people spend just to see him in the movie. There is no doubt that a golzar is a true star, with the least basic principles of acting such as unique auctions, the body ready to play roles, even action, expressing true and special, and a fascinating figure, but the lack of suitable films for such actors Iran has chosen to select some superficial films and, as it has been said, commercial films are worthy of this actor. The other positive thing is the film is the atmosphere of a happy and romantic film. The positive point is that the film definitely does not go into a comedic space, which was easily made possible. Basically, moving on the edge of the hedge that Mumbai moves on and does not fall on each side is one of the most important features of the movie. Salam Bombay, with all its strengths and weaknesses, is a film to be examined in the cinema of at least the present decade, which once again reminds the importance of fun and entertaining business cinema, as well as another example of cinematic productions that thirst for a cultural market and cinema is reminded of nothing but comedy. Ali Mansouri (2016) added "I wish that this film transcends the level of an Indian movie-maker who likes to be a good but never-so-fledged film, and has been a big step forward in changing the irrational trend of the Iranian cinema market."

\section{CONCLUSION}

Cinema is an integral part of Mass media. India and Iran has deep intense connectivity with the films. India and Iran has become a political and social institutions in the field of Cinema it is particular important on cultural identity. India is strongly promoting its Cinema as an important soft power tool worldwide. In social interactions, defensive strategies such as dressing fashion, pointers, and good faith are presented and are equally popular in India and Overseas. Films with popular themes and music are creating strong 
bilateral relationships and bonding relationships between the nations. Art and Culture provide huge potential to depict the social, cultural political and cultural realities. The main question of this study was how we can use this cultural aspect in the future for the better communication between these two communities. The researched came to this conclusion that the only thing can survive intercultural communication, is showing the reality through the most important medium of mass communication that is cinema.

\section{REFERENCES}

Akter, T., \& Dalkılıç, I. (2018). Aesthetic Pattern Forming of Ideological Messages in Turkish Cinema: Critical Analysis of "the Ottoman Republic "Movie. Online Journal of Communication and Media Technologies, 8(3), 165-180. https://doi.org/10.12973/ojemt/2620

Anderson, A. (2009). Media, politics and climate change: Towards a new research agenda. Sociology compass, 3(2), 166-182. https://doi.org/10.1111/j.1751-9020.2008.00188.x

Appadurai, A. (1990). Disjuncture and difference in the global cultural economy. Theory, culture \& society, 7(2-3), 295-310. https://doi.org/10.1177/026327690007002017

Chakravarty, S. S. (2007). Teaching Indian Cinema. Cinema Journal, 47(1), 105-108. https://doi.org/10.1353/cj.2007.0048

Chakravarty, S. S. (2011). National identity in Indian popular cinema, 1947-1987. University of Texas Press.

Corrigan, T., \& White, P. (2012). The film experience: An introduction. Macmillan.

Deshpande, A. (2007). Indian cinema and the bourgeois nation state. Economic and Political Weekly, 95-103.

Deshpande, A. (2007). Indian cinema and the bourgeois nation state. Economic and Political Weekly, 95-103.

Esfandiary, S. (2011). Mehrjui's Social Comedy and the Representation of the Nation in the Age of Globalization. Iranian Studies, 44(3), 341-358. https://doi.org/10.1080/00210862.2011.556385

Gaut, B. (1998). Imagination, Interpretation, and Film, Philosophical Studies: An International Journal for Philosophy in the Analytic Tradition

Grassilli, M. (2008) Migrant Cinema: Transnational and Guerrilla Practices of Film Production and Representation. Journal of Ethnic and Migration Studies, 34(8), 1237-1255. https://doi.org/10.1080/13691830802364825

Grassilli, M. (2008). Migrant cinema: Transnational and guerrilla practices of film production and representation. Journal of Ethnic and Migration Studies, 34(8), 1237 1255. https://doi.org/10.1080/13691830802364825

Gürkan, H., \& Ozan, R. (2015). Feminist cinema as counter cinema: Is feminist cinema counter cinema?

Hansen, T. (2011). The Importance of Foreign Films in Intercultural Communication.

Iwabuchi, K. (2010). Globalization, East Asian media cultures and their publics. Asian Journal of Communication, 20(2), 197-212. https://doi.org/10.1080/ 01292981003693385

Jenkins, H. (2004). The cultural logic of media convergence. International journal of cultural studies, 7(1), 33-43. https://doi.org/10.1177/1367877904040603

Kaur, R., \& Sinha, A. J. (Eds.). (2005). Bollyworld: Popular Indian cinema through a transnational lens. SAGE Publications India. 
Online Journal of Communication and Media Technologies, 2019

Laachir, K., \& Talajooy, S. (Eds.). (2013). Resistance in contemporary Middle Eastern cultures: Literature, cinema and music (Vol. 44). Routledge. https://doi.org/10.4324/9780203084915

Lim, K. F. (2006). Transnational collaborations, local competitiveness: mapping the geographies of filmmaking in/through Hong Kong. Geografiska Annaler: Series B, Human Geography, 88(3), 337-357. https://doi.org/10.1111/j.1468-0459.2006.00226.x

Livingston, P., \& Plantinga, C. (Eds.). (2008). The Routledge companion to philosophy and film. Routledge. https://doi.org/10.4324/9780203879320

Mehta, R. B., \& Pandharipande, R. V. (Eds.). (2011). Bollywood and globalization: Indian popular cinema, nation, and diaspora. Anthem Press.

Naficy, H. (2011). A Social History of Iranian Cinema, Volume 1: The Artisanal Era, 18971941 (Vol. 1). Duke University Press. https://doi.org/10.1215/9780822393009

Nandy, A. (Ed.). (1998). The secret politics of our desires: innocence, culpability and Indian popular cinema. Palgrave Macmillan.

Parr, H. (2007). Collaborative film-making as process, method and text in mental health research, Department of Geography, University of Dundee. https://doi.org/10.1177/1474474007072822

S. D. (2005). Sarkar: Re-presenting Amitabh Bachchan. Economic and Political Weekly, 40(38), 75-86. Retrieved on 15 January 2019 from https://www.epw.in/journal /2005/38/commentary/sarkar-re-presenting-amitabh-bachchan.html

Semati, M. (2007). Living with globalization and the Islamic state: An introduction to media, culture, and society in Iran. In Media, culture and society in Iran (pp. 17-30). Routledge. https://doi.org/10.4324/9780203934838

Seton, M. (1975). Problems of film making in Indi. India International Centre Quarterly, 2(2), 138-143.

Sharma, M. (2014). Transnational Cinema: A Cross Culture Communication Medium. $J$ Mass Communicat Journalism, 4(219), 2. https://doi.org/10.4172/2165-7912.1000219

Tapper, R. (Ed.). (2002). New Iranian Cinema: Politics, Representation and Identity. IB Tauris.

Tsivian, Y. (2008). "What Is Cinema?” An Agnostic Answer, Economic and Political Weekly. https://doi.org/10.1086/592543

White, J. (2003). Arguing with ethnography: the films of Bob Quinn and Pierre Perrault. Cinema Journal, 101-124. https://doi.org/10.1353/cj.2003.0006

White, P. (2015). Women's Cinema, World Cinema: Projecting Contemporary Feminisms. Duke University Press. https://doi.org/10.1215/9780822376019

Zeydabadi-Nejad, S. (2007). Iranian intellectuals and contact with the West: the case of Iranian cinema. British Journal of Middle Eastern Studies, 34(3), 375-398. https://doi.org/10.1080/13530190701388382

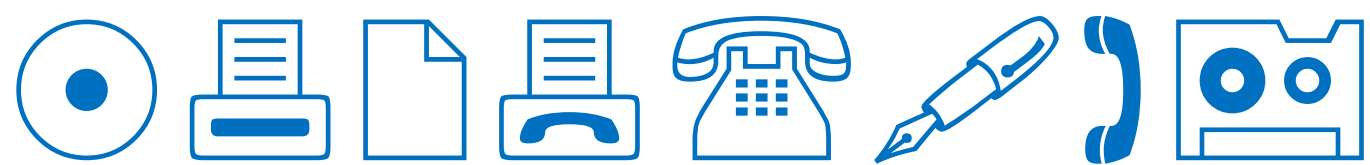

